\title{
Outbreak of neuropathogenic equid herpesvirus 1 causing abortions in Yili horses of Zhaosu, North Xinjiang, China
}

\author{
Panpan Tong ${ }^{1 \dagger}$, Ruli Duan ${ }^{1 \dagger}$, Nuerlan Palidan ${ }^{1 \dagger}$, Haifeng Deng ${ }^{2}$, Liya Duan ${ }^{1,3}$, Meiling Ren ${ }^{1,4}$, Xiaozhen Song ${ }^{1,5}$, \\ Chenyang Jia', Shuyao Tian', Enhui Yang ${ }^{1}$, Ling Kuang ${ }^{1 *}$ and Jinxin Xie ${ }^{1 *}$ (D)
}

\begin{abstract}
Background: EHV-1 is one of the most serious viral pathogens that frequently cause abortion in horses around the world. However, so far, relatively little information is available on EHV-1 infections as they occur in China. In January 2021, during an abortion storm which occurred in Yili horses at the Chinese State Studs of Zhaosu (North Xinjiang, China), 43 out of 800 pregnant mares aborted.
\end{abstract}

Results: PCR detection revealed the presence of EHV-1 in all samples as the possible cause of all abortions, although EHV-4, EHV-2 and EHV-5 were also found to circulate in the aborted fetuses. Furthermore, the partial ORF33 sequences of the 43 EHV-1 shared $99.3-100 \%$ and $99.0-100 \%$ similarity in nucleotide and amino acid sequences respectively. These sequences not only indicated a highly conserved region but also allowed the strains to group into six clusters. In addition, based on the predicted ORF30 nucleotide sequence, it was found that all the strains carried a guanine at the 2254 nucleotide position (aspartic acid at position 752 of the viral DNA polymerase) and were, therefore, identified as neuropathogenic strains.

Conclusion: This study is the first one that establishes EHV-1 as the cause of abortions in Yili horses, of China. Further characterization of the ORF30 sequences revealed that all the EHV-1 strains from the study carried the neuropathogenic genotype. Totally, neuropathogenic EHV-1 infection in China's horse population should be concerned although the virus only detected in Yili horse abortions.

Keywords: Yili horses, Abortion storm, Equid herpesvirus 1, ORF33 gene, ORF30 gene, Neuropathogenicity

\section{Background}

Equid herpesvirus 1 (EHV-1), classified within the family Herpesviridae, the subfamily Alphaherpesvirinae and the genus Varicellovirus [1], is one of the most serious viral pathogens of the horse population as it is frequently associated with abortion, respiratory problems as well as

*Correspondence: kuangling62@126.com; xiejinxin198683@163.com †Panpan Tong, Ruli Duan and Nuerlan Palidan contributed equally to this work.

${ }^{1}$ Laboratory of Animal Etiology and Epidemiology, College of Veterinary Medicine, Xinjiang Agricultural University, Urumqi, Xinjiang, China Full list of author information is available at the end of the article both ocular and neurological diseases in horses. As such, it can have a significant impact not only on equine health but also on the overall equine industry around the world [2-7].

EHV-1 possesses a $150 \mathrm{kbp}$ double-stranded DNA genome which encodes up to 80 open reading frames (ORFs) [8-10]. Among these, ORF33, encoding the envelope glycoprotein $\mathrm{B}(\mathrm{gB})$, possesses a conserved region that is frequently targeted for diagnostic PCR and phylogenetic analyses [11]. Similarly, ORF30 encodes the viral DNA polymerase which is strongly but not exclusively associated with both non-neuropathogenic or 
neuropathogenic EHV-1 depending on whether an adenine (A) or guanine (G) is present at position 2254 respectively. This, in turn, corresponds to an asparagine (N) or aspartic acid (D) at amino acid position 752 of the viral DNA polymerase, respectively [11-24].

In January 2021, 43 Yili horses from the Chinese State Studs of Zhaosu (Northern Xinjiang, China) aborted without any additional clinical signs. These were part of a population of 820 horses of which 20 were Thoroughbred stallions (> eight years of age) and 800 were mares ( $>$ four years of age) at approximately six months of gestation. In fact, horses of this farm had no vaccination scheduled, and they encountered abortion storms every year. In order to establish viral pathogens as the possible cause of these abortions, lung tissues of all aborted fetuses were analyzed by PCR to check for the presence of EHV-1, equid herpesvirus 4 (EHV-4), equid herpesvirus $2(\mathrm{EHV}-2)$ and equid herpesvirus 5 (EHV-5). In addition, the ORF30 and ORF33 genes of EHV-1 strains detected in the samples of aborted fetuses were further characterized. This study is the first to have been carried out on viruses responsible for abortion in the Yili horses of Xinjiang, one of the major horse-producing regions in China. In fact, in a general way, this work also represents the first to investigate viruses related to horse abortion in the country.

\section{Results}

\section{EHV detection}

The PCR results confirmed the presence of EHV-1, EHV-4, EHV-2 and EHV-5 in the lung tissues of aborted fetuses, with the percentage of positive cases for each virus being $100 \%$ (43/43), 2.3\% (1/43), 7\% (3/43) and $16.3 \%$ (7/43), respectively. Coinfection with EHV-1, EHV-4 and EHV-5 was detected in one aborted sample, coinfection with EHV-1, EHV-2, and EHV-5 was detected in three aborted samples, and coinfection with EHV-1 and EHV-5 was detected in three aborted samples. These results, therefore, suggested that EHV-1 could have been the cause of the abortion storm in the Yili horses.

\section{ORF33 sequences comparison and phylogenetic analysis} Comparison of the partial ORF33 (592nt) sequences from the $43 \mathrm{EHV}-1$ positive samples revealed a nucleotide and amino acid similarity level of $99.3-100 \%$ and 99.0-100\%, respectively (accession nos: MZ561483MZ561525), thus indicating that the partial ORF33 genes of China's EHV-1 had a high sequence similarity. In addition, these sequences were also compared with those of EHV-1 reference strains identified in the United Kingdom (V592: accession no. AY464052, Ab4: accession no. AY665713, and Suffolk/123/2005: accession no. KU206480), in Japan (NY03: accession no.
KF644569), in the United States (T953_P210/2015: accession no. KR047045), in India (Hisar-14/2014: accession no. MN912433), in China (YM2019: accession no. MT063054) and in Belgium (BE/21P43_BD5: accession no. MW855960). In this case, the results indicated a percentage similarity level of $99.5-100 \%$ and $99.0-100 \%$ for DNA and amino acid sequences (Table 1), respectively. Finally, a phylogenic network representation which was constructed based on those partial ORF33 nucleotide sequences revealed that EHV-1 strains in this study were clustered into six different clusters (Fig. 1).

\section{ORF30 sequences analysis}

To investigate whether the 43 EHV-1 strains detected in this study were neuropathogenic or non-neuropathogenic in nature, partial PCR amplification of the ORF30 gene of EHV-1 (559 nt) was performed using specific primers (Table S1). In this case, the results showed that the partial ORF30 sequences of the $43 \mathrm{EHV}-1$ positive samples had $100 \%$ identity in their nucleotide and amino acid sequences (accession nos: OM047215-OM047257), hence indicating a high genetic conservation. Furthermore, in a similar way to the neuropathogenic EHV-1 referenced strains Ab4 and T953_P210, the ORF30 sequences of the 43 EHV1 strains of the study carried a guanidine (G) at position 2254 (D in position 752 of the viral DNA polymerase) (Fig. 2), and the detected strains were, therefore, identified as neuropathogenic EHV-1.

\section{Discussion}

Horses represent a natural host for alphaherpesviruses (EHV-1 and EHV-4), and gammaherpesviruses (EHV-2 and EHV-5) $[2,16]$, with EHV-1 being the most common viral cause of abortion storms in horses.

Usually, these four EHVs occur together in aborted samples $[2,16]$ and hence, the findings of this study are in agreement with published reports regarding the detection of EHV-2, EHV-4, and EHV-5 as co-infections in aborted fetuses [2]. However, although coinfections with EHV-2 (accession nos: OK362329-OK362331), EHV-4 (accession no: OK362332), EHV-5 (accession nos: OL440383-OL440384) alongside EHV-1 were detected, only the latter was identified in all the fetal samples of the unvaccinated Yili horses. Therefore, the results suggested that EHV-1 could have been the main cause of the abortion storm in the Yili horse population included in this study. In fact, this is supported by previous results which revealed that EHV-1 was frequently involved in outbreaks that led to horse abortions around the world [2, 11-24]. Regarding the other viruses, EHV-4 is known to provoke sporadic abortions, but it has not yet been demonstrated whether EHV-2 and EHV-5 are also a cause for concern $[16,25,26]$. Given that these three viruses were 
Table 1 Nucleotide (upper right) and amino acid (bottom left) similarity of the ORF33 sequence between EHV-1 identified in this study and EHV-1 reference strains

\begin{tabular}{|c|c|c|c|c|c|c|c|c|c|}
\hline & $\begin{array}{l}43 \text { EHV-1 } \\
\text { detected in } \\
\text { this study }\end{array}$ & EHV-1 Ab4 & EHV-1 NY03 & $\begin{array}{l}\text { EHV-1 T953_ } \\
\text { P210 }\end{array}$ & $\begin{array}{l}\text { EHV-1 } \\
\text { Suffolk/123 }\end{array}$ & $\begin{array}{l}\text { EHV-1 Hisar- } \\
14\end{array}$ & $\begin{array}{l}\text { EHV-1 } \\
\text { YM2019 }\end{array}$ & $\begin{array}{l}\text { EHV-1 } \\
\text { BE/21P43_ } \\
\text { BD5 }\end{array}$ & EHV-1 V592 \\
\hline $\begin{array}{l}43 \text { EHV-1 } \\
\text { detected } \\
\text { in this study }\end{array}$ & & 99.7-100 & 99.7-100 & $99.7-100$ & 99.7-100 & 99.7-100 & $99.7-100$ & $99.5-99.8$ & $99.5-99.8$ \\
\hline $\begin{array}{l}\text { EHV-1 } \\
\text { Ab4 }\end{array}$ & $99.5-100$ & & 100 & 99.9 & 99.9 & 99.8 & 100 & 99.9 & 99.9 \\
\hline $\begin{array}{l}\text { EHV-1 } \\
\text { NY03 }\end{array}$ & $99.5-100$ & 100 & & 99.9 & 99.9 & 99.8 & 100 & 99.9 & 99.9 \\
\hline $\begin{array}{l}\text { EHV-1 } \\
\text { T953_P210 }\end{array}$ & $99.5-100$ & 99.7 & 99.7 & & 99.9 & 99.9 & 99.9 & 99.9 & 99.9 \\
\hline $\begin{array}{l}\text { EHV-1 } \\
\text { Suffolk/123 }\end{array}$ & $99.5-100$ & 99.9 & 99.9 & 99.8 & & 99.8 & 99.9 & 99.9 & 99.9 \\
\hline $\begin{array}{l}\text { EHV-1 } \\
\text { Hisar-14 }\end{array}$ & $99.5-100$ & 99.8 & 99.8 & 99.9 & 99.9 & & 99.8 & 99.8 & 99.9 \\
\hline $\begin{array}{l}\text { EHV-1 } \\
\text { YM2019 }\end{array}$ & $99.5-100$ & 100 & 100 & 99.7 & 99.9 & 99.8 & & 99.9 & 99.9 \\
\hline $\begin{array}{l}\text { EHV-1 } \\
\text { BE/21P43_ } \\
\text { BD5 }\end{array}$ & $99.0-99.5$ & 99.7 & 99.7 & 99.8 & 99.8 & 99.9 & 99.7 & & 99.9 \\
\hline $\begin{array}{l}\text { EHV-1 } \\
\text { V592 }\end{array}$ & $99.5-100$ & 99.8 & 99.8 & 99.9 & 99.9 & 100 & 99.8 & 99.9 & \\
\hline
\end{tabular}

detected in the EHV-1 positive aborted samples, there is the need to isolate them in order to demonstrate whether they can be the cause of abortion in Yili horses. In this context, a previous study actually noted that these three viruses circulated in thoroughbred foals with respiratory diseases in North Xinjiang [27], but here, the detection of these strains is being reported for the first time in abortion cases of horses in North Xinjiang. Therefore, based on the results, it can be concluded that EHV-2, EHV-4 and EHV-5 might contribute to abortions and respiratory diseases in the horses of Xinjiang, China.

In a similar way to one previous study, some variations in ORF33 genes of the EHV-1 viruses were also detected in the aborted samples [11]. Indeed, the partial ORF33 (592 nt) sequences from the 43 EHV-1 shared 99.3-100\% nt identity, and clustered into six groups, thereby indicating genetic diversity.

Previous studies have shown that the nucleotide at position 2254 of ORF30 was strongly associated with the occurrence of EHV-1 neurological diseases [11-24]. For instance, most of the viruses recovered from abortion cases worldwide contained adenine (A) at this position (asparagine $(\mathrm{N})$ at position 752 of the protein) and belonged to non-neuropathogenic strains (associated with non-neurological conditions) [11-24]. Similarly, as reported by Smith et al. (2010), G2254 strains have been isolated less frequently than A2254 ones in abortion cases [15]. However, in this study, the ORF30 sequences of $43 \mathrm{EHV}-1$ detected in the present study carried a $\mathrm{G}$ at position 2254 (D in position 752) (Fig. 2). Hence, the data provided evidence that neuropathogenic EHV-1 could have been responsible for the series of abortions in Yili horses. It should nevertheless be noted that comparative sequence analysis also showed similarity to EHV-1 YM2019 (accession no. MT063054) which, according to GenBank information, is non-neuropathogenic and was identified in aborted samples of Przewalski's horses. As such, the results indicated that both non-neuropathogenic and neuropathogenic EHV-1 strains could be circulating in the horse population of Xinjiang, China. Indeed, while non-neuropathogenic EHV-1 had been detected from some cases of neurological diseases, in most cases, neuropathogenic EHV-1 was associated with the development of neurological diseases, higher levels of viraemia as well as longer disease duration. For instance, in Argentina, the United Kingdom and the United States, approximately $8.7-50 \%$ of neuropathogenic EHV-1, identified from abortion cases, were associated with neurological disease $[12,14]$. These data clearly supported the results regarding the presence of neuropathogenic EHV-1 in Yili horses despite the absence of neurological signs.

Several published studies showed that only non-neuropathogenic EHV-1 are isolated in Brazil, Turkey and Poland $[13,17,18]$. Neuropathogenic EHV-1 has a low prevalence in Japan (2.7\%), the United States (10.819.4\%), Argentina (7.4\%), France (24\%), and Germany 


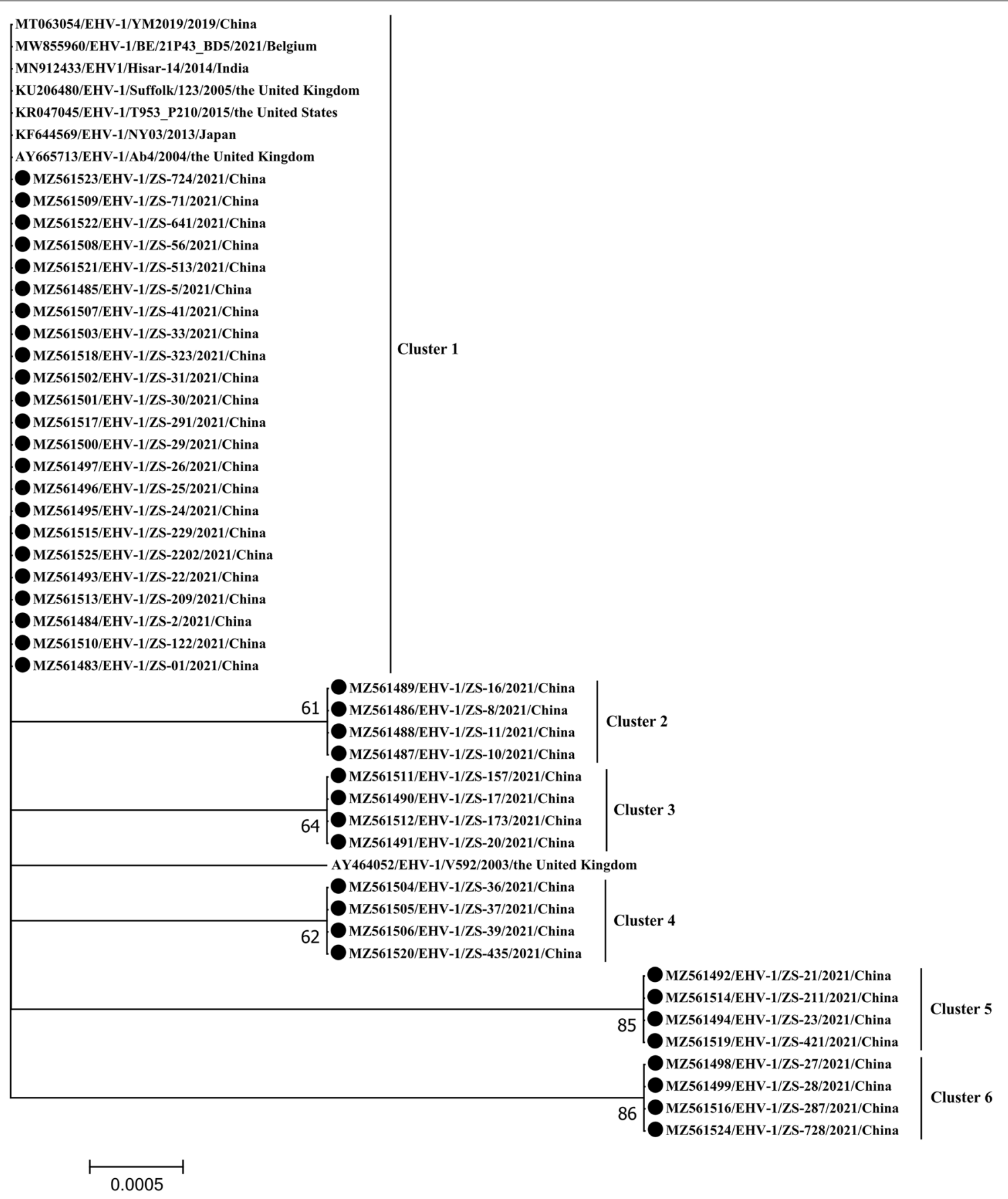

Fig. 1 Phylogenic network representation based on EHV-1 ORF33 gene sequences using the maximum-likelihood method based on the TamuraNei model (MEGA7). The black circles indicate the EHV-1 strains identified in this study

(10.6\%) [4, 14, 15, 19-21], but a high prevalence in Italy (90\%), Uruguay (92.3\%) and Ethiopia (98.9\%) [11, 22, 23]. However, over the past few decades, two investigations conducted in Italy and the United States indicated that the prevalence of neuropathogenic EHV-1 was on the rise. In addition, even though vaccination could reduce virus spreading, one study in Germany reported that vaccination against EHV-1 was not always successful at preventing the spread of the neuropathogenic genotype [24], with another study in Italy confirming that the spread of neuropathogenic EHV-1 strains were could be observed in both vaccinated mares as well as unvaccinated horses 


\begin{tabular}{|c|c|c|c|c|}
\hline & $\mathbf{A}$ & & B & \\
\hline & & 2,254 & & 752 \\
\hline & & 1 & & \\
\hline KU206480/EHV-1 Suffolk/123 & TCAACCATCC & GTCAACTACT & EVDL AGLQPS & VNYSTFEVGD \\
\hline KF644569/EHV-1 NY03 & $\ldots \ldots$ & $\ldots \ldots$ & $\ldots \ldots \ldots$ & $\ldots \ldots$ \\
\hline MT063054/EHV-1 YM2019 & $\ldots \ldots$ & $\ldots \ldots$ & $\ldots \ldots$ & $\ldots \ldots \ldots$ \\
\hline MN912433/EHV-1 Hisar-14 & $\ldots . .$. & $\ldots \ldots$ & $\ldots \ldots$ & .......... \\
\hline MW855960/EHV-1 BE/21P43_BD5 & ........ & $\ldots \ldots$ & ........ & $\cdots$ \\
\hline AY464052/EHV-1 V592 & $\ldots \ldots$ & $\ldots \ldots$ & $\ldots \ldots$ & $\ldots$ \\
\hline KR047045/EHV1 T953_P210 & ........ & $\ldots G \ldots .$. & ........ & 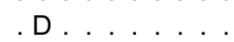 \\
\hline AY665713/EHV-1 Ab4 & $\ldots . . .$. & $\ldots G \ldots .$. & $\ldots \ldots$ & D ...... \\
\hline OM047215/EHV-1 ZS-01 & $\ldots . .$. & $\ldots G \ldots$ & $\ldots \ldots$ & D ....... \\
\hline OM047216/EHV-1 ZS-2 & $\ldots \ldots$ & $\ldots G \ldots$ & $\ldots \ldots$ & D ....... \\
\hline OM047217/EHV-1 ZS-5 & $\ldots \ldots$ & $\ldots G \ldots$ & $\ldots \ldots$ & 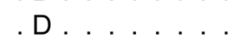 \\
\hline OM047218/EHV-1 ZS-8 & ........ & $\ldots G \ldots$ & $\ldots \ldots$ & $D \ldots \ldots$ \\
\hline OM047219/EHV-1 ZS-10 & $\ldots . . .$. & $\ldots G \ldots$ & 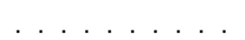 & D .......... \\
\hline OM047220/EHV-1 ZS-11 & $\ldots \ldots$ & $\ldots G \ldots \ldots$ & 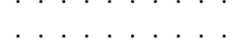 & 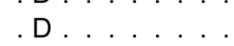 \\
\hline OM047221/EHV-1 ZS-16 & $\ldots \ldots$ & $\ldots G \ldots$ & ....... & 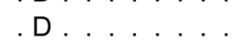 \\
\hline OM047222/EHV-1 ZS-17 & ........ & $\ldots G \ldots$ & 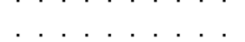 & 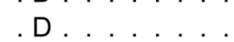 \\
\hline OM047223/EHV-1 ZS-20 & ....... & $\ldots G \ldots$ & ....... & 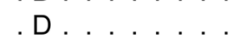 \\
\hline OM047224/EHV-1 ZS-21 & ........ . & $\ldots G \ldots$ & ..... & 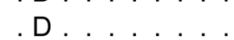 \\
\hline OM047225/EHV-1 ZS-22 & ........ & . G. . . . & $\ldots$ & D $\ldots$ \\
\hline OM047226/EHV-1 ZS-23 & ........ & $\ldots G . .$. & . & D $\ldots$ \\
\hline OM047227/EHV-1 ZS-24 & ........ & . G.... & . & $\mathrm{D}$ \\
\hline OM047228/EHV-1 ZS-25 & ........ & . G. . . . & ( & $D$ \\
\hline OM047229/EHV-1 ZS-26 & ...... & . G... & a & (3............. \\
\hline & ....... & G... & a & (............. \\
\hline OM047231/EHV-1 ZS-28 & ....... & G.... & $\cdots \cdots$ & D............ \\
\hline OM047232/EHV-1 ZS-29 & $\ldots \ldots \ldots$ & G.... & $\cdots \cdots \cdots$ & D........... \\
\hline OM047233/EHV-1 ZS-30 & ....... & $G$ & $\cdots \cdots \cdots$ & $D \ldots \ldots$ \\
\hline & (n) & & $\ldots \ldots$ & $D \ldots \ldots$ \\
\hline OM047234/EHV-1 ZS-31 & & $\ldots G \ldots$ & $\ldots \ldots \ldots$ & $D \ldots \ldots$ \\
\hline OM047235/EHV-1 ZS-33 & $\ldots \ldots$ & $\ldots G \ldots$ & $\ldots \ldots$ & $D \ldots \ldots$ \\
\hline OM047236/EHV-1 ZS-36 & $\ldots \ldots$ & $\ldots G \ldots$ & $\ldots \ldots$ & $D \ldots \ldots$. \\
\hline OM047237/EHV-1 ZS-37 & $\ldots \ldots$ & $\ldots G \ldots$ & ...... & D .......... \\
\hline OM047238/EHV-1 ZS-39 & $\ldots \ldots$ & $\ldots G \ldots$ & ........ & 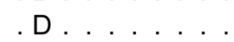 \\
\hline OM047239/EHV-1 ZS-41 & $\ldots \ldots$ & $\ldots G \ldots$ & $\ldots \ldots$ & $D \ldots \ldots$ \\
\hline OM047240/EHV-1 ZS-56 & $\ldots \ldots$ & $\ldots G \ldots$ & ....... & 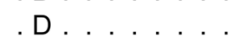 \\
\hline OM047241/EHV-1 ZS-71 & $\ldots \ldots$ & $\ldots G \ldots$ & ...... & D .......... \\
\hline OM047242/EHV-1 ZS-122 & $\ldots \ldots$ & $\ldots G \ldots$ & ...... & 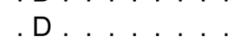 \\
\hline OM047243/EHV-1 ZS-157 & ........ & $\ldots G \ldots$ & 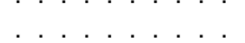 & 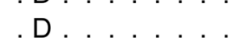 \\
\hline OM047244/EHV-1 ZS-173 & $\ldots . . .$. & $\ldots G \ldots \ldots$ & 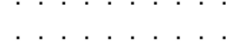 & 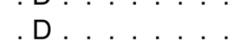 \\
\hline OM047245/EHV-1 ZS-209 & ......... & . G. . . . & $\ldots$ & 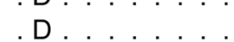 \\
\hline OM047246/EHV-1 ZS-211 & ........ & . G. . . . & $\ldots$ & $\cdots$ \\
\hline OM047247/EHV-1 ZS-229 & ........ & $\ldots G \ldots \ldots$ & $\ldots \ldots$ & $\ldots$ \\
\hline OM047248/EHV-1 ZS-287 & ....... & $\ldots G \ldots$ & ( s s & D \\
\hline OM047249/EHV-1 ZS-291 & ........ & . G.... & $\ldots$ & $\mathrm{D}$ \\
\hline OM047250/EHV-1 ZS-323 & ....... & . G..... & . & $\mathrm{D}$ \\
\hline OM047251/EHV-1 ZS-421 & ....... & . G..... & 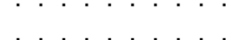 & n.......... \\
\hline OM047252/EHV-1 ZS-435 & ....... & 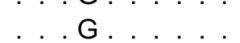 & $\cdots$ & ... \\
\hline OM047253/EHV-1 ZS-513 & 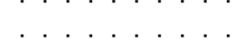 & 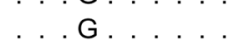 & $\cdots \cdots$ & D...... \\
\hline OM047254/EHV-1 ZS-641 & $\ldots$ & 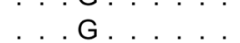 & $\cdots \cdots \cdots$ & D....... \\
\hline OM047255/EHV-1 ZS-724 & 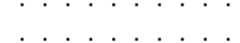 & $\cdots G$ & .............. & D..... \\
\hline OM047255/EHV-1 ZS-724 & . & $\cdots G \ldots$ & ............. & D...... \\
\hline OM047256/EHV-1 ZS-728 & & $\ldots G \ldots$ & $\ldots \ldots \ldots$ & D. . \\
\hline OM047257/EHV-1 ZS-2202 & $\ldots \ldots$ & $\ldots G \ldots$ & $\ldots \ldots$ & D..... \\
\hline Ig. 2 Analysis of ORF30 gene sequence. & Shows the presence & f G2254 polymorphis & strains from this stuc & B Shows the \\
\hline 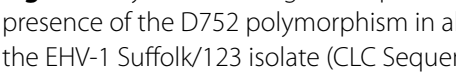 & (ing) & 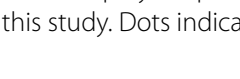 & पe & 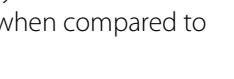 \\
\hline
\end{tabular}

[11]. Thus, it is not surprising that all EHV-1 detected in aborted samples from unvaccinated Yili horses, could have been neuropathogenic EHV-1.
Furthermore, two recent studies in France and the United States identified a new EHV-1 DNA polymerase (ORF30) genotype. This was followed by the isolation of 
a C2254/H752 which was then associated with both respiratory and neurological clinical signs [28, 29]. Further study will investigate the presence of this new EHV-1 genotype in China's horses.

\section{Conclusion}

In summary, EHV-1, EHV-4, EHV-5 and EHV-2 were detected from samples of aborted fetuses, and as such, it was shown that EHV-1 could have been the cause of the abortion storm. Further characterization of the EHV-1 provided evidence that the neuropathogenic form of EHV-1 could have been involved. It is expected that this study will create awareness about the role of neuropathogenic EHV-1 in horse abortions in China, and promote the development of vaccines against the virus.

\section{Methods}

\section{Sample collection}

In January 2021, 43 out of 800 pregnant Yili mares from the Chinese State Studs of Zhaosu (Northern Xinjiang, China) aborted. Lung tissues of each aborted fetus were, therefore, transferred to a tube containing $10 \mathrm{~mL}$ of phosphate buffer for storage at $-80^{\circ} \mathrm{C}$ until required for analysis.

\section{Viral nucleic acids extraction and sequencing}

Lung tissue samples were ground and after centrifugation, viral nucleic acids were extracted from $200 \mu \mathrm{L}$ of the supernatant (Geneaid Biotech Co.) by following the manufacturer's instructions. The presence of EHV-1 (592 nt), EHV-2 (716nt), EHV-4 (587nt) and EHV-5 (881 nt) DNA in these nucleic acid samples was subsequently detected by PCR by targeting partial ORF33 (EHV-1 or EHV-4) or ORF8 (EHV-5 or EHV-2) genes (encoding the $\mathrm{gB}$ ). For this purpose, primers were designed using publicly-available sequences in GenBank (accession nos: AY464052, LC075585, MK904567 and KC715730, Table S1) while the PCR itself was carried out using the TIANSeq HiFi Amplification Mix (Tiangen Biotech) with the following PCR conditions: an initial denaturation at $94^{\circ} \mathrm{C}$ for $2 \mathrm{~min}$, followed by 35 cycles, each with a denaturation step at $98^{\circ} \mathrm{C}$ for $10 \mathrm{~s}$, as well as both an annealing and an extension step, each at $68^{\circ} \mathrm{C}$ for $30 \mathrm{~s}$. Eventually a final extension at $68^{\circ} \mathrm{C}$ for $5 \mathrm{~min}$ was performed. Positive PCR amplicons were then ligated into a $p E A S Y^{\circledR}$-Blunt $\mathrm{T}$ vector (TransGen Biotech) for transforming $E$. coli DH5a competent cells (Tiangen Biotech) and ten clones of each amplicon were eventually selected for Sanger sequencing (Sangon Biotech).
Multiple sequences comparison and phylogenetic analyses Detailed information (GenBank accession nos) of the sequences used in this study is provided in Fig. 1. All of the partial ORF33 and ORF30 nucleotide sequences of EHV-1 which were generated in this study were submitted to GenBank, with the following accession nos: MZ561483-MZ561525 and OM047215-OM047257. Sequences were analyzed by MegAlign software in Lasergene v7.1 and a phylogenic network representation of all target sequences was generated using the maximumlikelihood method based on the Tamura-Nei model of MEGA7. The accuracy of tree topologies was also evaluated using 1000 bootstrap replicates [30].

\section{Abbreviations}

EHV: Equid herpesvirus; ORF: Open reading frame; G: Guanidine; A: Adenine; N: Asparagine; D: Aspartic acid.

\section{Supplementary Information}

The online version contains supplementary material available at https://doi. org/10.1186/s12917-022-03171-1.

Additional file 1: Table S1. Primer Sequences used in this study.

\section{Acknowledgements}

No applicable.

\section{Authors' contributions}

P.T. and J.X. performed the research, analyzed the data, and drafted the manuscript. R.D., N.P., H.D., L.D., M.R., X.S., C.J., S.T., E.Y., L.K. contributed to the collection of samples and detection of PCR. P.T., L.K. and J.X. revised the manuscript. J.X. conceived the study, carried out additional analyses and finalized the manuscript. All authors contributed to the revising of the manuscript. The authors read and approved the final manuscript.

\section{Funding}

This study was supported by a National Natural Science Foundation of China (32060808), China Postdoctoral Science Foundation (2019M653901XB),

The Natural Science Foundation of Xinjiang Uyghur Autonomous Region (2019D01A47), Post-doctoral Science Foundation of Xinjiang Agricultural University (XJAU20180723) and Xinjiang Uygur Autonomous Region High-Level Talent Introduction (XJ20171123) grants.

\section{Availability of data and materials}

All data generated or analyzed during this study are included in this published article and its additional files. Sequences of EHV-1 from aborted fetuses generated in this study have been submitted to GenBank under accession nos: MZ561483-MZ561525 and OM047215-OM047257.

\section{Declarations}

\section{Ethics approval and consent to participate}

All experimental procedures involving animals were approved by the Animal Care and Use Committee of Xinjiang Agricultural University, Urumqi, Xinjiang, China under animal protocol number: 2020012 and performed according to the Animal Ethics Procedures and Guide-lines of the Ministry of Agriculture of China. Lung tissues of aborted fetuses were collected by the farm's veterinarian according to the approved procedures. The owner gave informed written consent for the lung tissues of aborted fetuses to be included in the study. The study was carried out in compliance with the ARRIVE guidelines. 


\section{Consent for publication \\ No applicable.}

\section{Competing interests}

The authors have declared no competing interests.

\section{Author details}

${ }^{1}$ Laboratory of Animal Etiology and Epidemiology, College of Veterinary Medicine, Xinjiang Agricultural University, Urumai, Xinjiang, China. ${ }^{2}$ Zhaosu Horse Barn in Yili, Zhaosu, China. ${ }^{3}$ Center of Animal Disease Control and Prevention, Acheng District, Harbin, Heilongjiang, China. ${ }^{4}$ Cisen Pharmaceutical Co., Ltd, Jining, Shandong, China. ${ }^{5}$ Tiankang biological Co., Ltd, Urumqi, Xinjiang, China.

Received: 20 October 2021 Accepted: 3 February 2022

Published online: 01 March 2022

\section{References}

1. Davison AJ. Herpesvirus systematics. Vet Microbiol. 2010;143(1):52-69.

2. Smith KC, Blunden AS, Whitwell KE, Dunn KA, Wales AD. A survey of equine abortion, stillbirth and neonatal death in the UK from 1988 to 1997. Equine Vet J. 2003;35(5):496-501.

3. Laval K, Poelaert KCK, Van Cleemput J, Zhao J, Vandekerckhove AP, Gryspeerdt AC, et al. The pathogenesis and immune evasive mechanisms of equine herpesvirus type 1. Front Microbiol. 2021;12:662686.

4. Fritsche AK, Borchers K. Detection of neuropathogenic strains of equid Herpesvirus 1 (EHV-1) associated with abortions in Germany. Vet Microbiol. 2011;147(1-2):176-80.

5. Garvey M, Lyons R, Hector RD, Walsh C, Arkins S, Cullinane A. Molecular characterisation of equine herpesvirus 1 isolates from cases of abortion, respiratory and neurological disease in Ireland between 1990 and 2017. Pathogens. 2019;8(1):7.

6. Khusro A, Aarti C, Rivas-Caceres RR, Barbabosa-Pliego A. Equine herpesvirus-l infection in horses: recent updates on its pathogenicity, vaccination, and preventive management strategies. J Equine Vet Sci. 2020;87:102923.

7. Yang YL, Liu JH, Song HT, Li J, Lu YB, Hu Y, et al. Isolation and identification of equine herpesvirus 1 in Xinjiang. Chin J Prevent Vet Med. 2016;38(07):550-3 (In Chinese).

8. Burton EA, Wechuck JB, Wendell SK, Goins WF, Fink DJ, Glorioso JC. Multiple applications for replication-defective herpes simplex virus vectors. Stem Cells. 2001;19(5):358-77.

9. Patel JR, Heldens J. Equine herpesviruses 1 (EHV-1) and 4 (EHV-4)--epidemiology, disease and immunoprophylaxis: a brief review. Vet J. 2005;170(1):14-23.

10. Telford EA, Watson MS, McBride K, Davison AJ. The DNA sequence of equine herpesvirus-1. Virology. 1992;189(1):304-16.

11. Preziuso S, Sgorbini M, Marmorini P, Cuteri V. Equid alphaherpesvirus 1 from Italian horses: evaluation of the variability of the ORF30, ORF33, ORF34 and ORF68 genes. Viruses. 2019;11(9):851.

12. Nugent J, Birch-Machin I, Smith KC, Mumford JA, Swann Z, New-ton $J R$, et al. Analysis of equid herpesvirus 1 strain variation reveals a point mutation of the DNA polymerase strongly associated with neuropathogenic versus nonneuropathogenic disease outbreaks. J Virol. 2006;80(8):4047-60.

13. Stasiak K, Dunowska M, Rola J. Outbreak of equid herpesvirus 1 abortions at the Arabian stud in Poland. BMC Vet Res. 2020;16(1):374.

14. Vissani MA, Becerra ML, Olguín Perglione C, Tordoya MS, Miño S, Barrandeguy M. Neuropathogenic and non-neuropathogenic genotypes of Equid Herpesvirus type 1 in Argentina. Vet Microbiol. 2009;139(3-4):361-4.

15. Smith KL, Allen GP, Branscum AJ, Frank Cook R, Vickers ML, Timoney PJ, et al. The increased prevalence of neuropathogenic strains of EHV-1 in equine abortions. Vet Microbiol. 2010;141(1-2):5-11.

16. Leon A, Fortier G, Fortier C, Freymuth F, Tapprest J, Leclercq R, et al. Detection of equine herpesviruses in aborted foetuses by consensus PCR. Vet Microbiol. 2008;126(1):20-9.

17. Mori E, Lara do Carmo CSH, Lara M, Cunha EMS, Villalobos EMC, Mori CMC, Soares RM, Brandao PE, Fernandes WR, Richtzenhain LJ. Molecular characterization of Brazilian equid herpesvirus type 1 strains based on neuropathogenicity markers. Braz. J Microbiol. 2015;46(2):565-70.
18. Turan N, Yildirim F, Altan E, Sennazli G, Gurel A, Diallo I, et al. Molecular and pathological investigations of EHV-1 and EHV-4 infections in horses in Turkey. Res Vet Sci. 2012;93(3):1504-7.

19. Perkins GA, Goodman LB, Tsujimura K, Van de Walle GR, Kim SG, Dubovi $E J$, et al. Investigation of the prevalence of neurologic equine herpes virus type 1 (EHV-1) in a 23-year retrospective analysis (1984-2007). Vet Microbiol. 2009;139(3):375-8.

20. Pronost S, Leon A, Legrand L, Fortier C, Miszczak F, Freymuth F, et al. Neuropathogenic and non-neuropathogenic variants of equine herpesvirus 1 in France. Vet Microbiol. 2010;145(3):329-33.

21. Tsujimura K, Oyama T, Katayama Y, Muranaka M, Bannai H, Nemoto M, et al. Prevalence of equine herpesvirus type 1 strains of neuropathogenic genotype in a major breeding area of Japan. J Vet Med Sci. 2011;73(12):1663-7.

22. Castro ER, Arbiza J. Detection and genotyping of equid herpesvirus 1 in Uruguay. Rev Sci Tech. 2017;36(3):799-806.

23. Negussie H, Gizaw D, Tessema TS, Nauwynck HJ. Equine herpesvirus-1 myeloencephalopathy, an emerging threat of working equids in Ethiopia. Transbound Emerg Dis. 2017;64(2):389-97.

24. Damiani AM, de Vries M, Reimers G, Winkler S, Osterrieder N. A severe equine herpesvirus type 1 (EHV-1) abortion outbreak caused by a neuropathogenic strain at a breeding farm in northern Germany. Vet Microbiol. 2014;172(3):555-62.

25. Izume S, Kirisawa R, Ohya K, Ohnuma A, Kimura T, Omatsu T, et al. The full genome sequences of 8 equine herpesvirus type 4 isolates from horses in Japan. J Vet Med Sci. 2017;79(1):206-12.

26. Galosi CM, de la Paz VC, Fernández LC, Martinez JP, Craig MI, Barrandeguy $M$, et al. Isolation of equine herpesvirus- 2 from the lung of an aborted fetus. J Vet Diagn Investig. 2005;17(5):500-2.

27. Xie JX, Tong PP, Zhang L, Ren ML, Song XZ, Jia CY, et al. First detection and genetic characterization of equid herpesvirus 4, 2 and 5 in China. Arch Virol. 2021;166(5):1421-6.

28. Sutton G, Thieulent C, Fortier C, Hue ES, Marcillaud-Pitel C, Pléau A, et al. Identification of a new equid herpesvirus 1 DNA polymerase (ORF30) genotype with the isolation of a C2254/H752 strain in French horses showing no major impact on the strain behaviour. Viruses. 2020;12(10):1160.

29. Pusterla N, Barnum S, Miller J, Varnell S, Dallap-Schaer B, Aceto H, et al. Investigation of an EHV-1 outbreak in the United States caused by a new H752 genotype. Pathogens. 2021;10(6):747.

30. Kumar S, Stecher G, Tamura K. MEGA7: molecular evolutionary genetics analysis version 7.0 for bigger datasets. Mol Biol Evol. 2016;33(7):1870-4.

\section{Publisher's Note}

Springer Nature remains neutral with regard to jurisdictional claims in published maps and institutional affiliations.

Ready to submit your research? Choose BMC and benefit from:

- fast, convenient online submission

- thorough peer review by experienced researchers in your field

- rapid publication on acceptance

- support for research data, including large and complex data types

- gold Open Access which fosters wider collaboration and increased citations

- maximum visibility for your research: over 100M website views per year

At BMC, research is always in progress.

Learn more biomedcentral.com/submissions 